\title{
Linguistic deviation and the rhetoric figures in Shakespeare's selected plays
}

\author{
Fathu Rahman - Sukardi Weda
}

DOI: 10.18355/XL.2019.12.01.03

\begin{abstract}
This research is the study of linguistic deviation is one of linguistic analysis in literary studies. The purpose was to uncover the linguistic deviation found in Shakespeare's plays. It should be considered important and helpful for foreign readers (non-native speakers of English) to have a better understanding of the stylistics used in Shakespeare's plays. The analysis applied was language-based. As a great author who lived in the transitional period from Old to Modern English, Shakespeare has been credited with encouraging the birth of new English, and his contribution has been recorded in the history of the English Language. His rhetoric remains topical and has continued to captivate readers through several centuries. His plays are still learned in many parts of the world. The objectives of the study are 1) to inventory a number of linguistic deviations contained in Shakespeare's works, 2) to find out the types of rhetorical style in Shakespeare's linguistic deviation, and 3) to determine to what the extent of respondents (non-native English) failed to understand the linguistic deviation in Shakespeare's works. However, the language that Shakespeare used in his plays, besides sustaining the beauty of the style, it also contains a number of linguistic deviations. His specific deviations and the stylistics concerned were the topics of this qualitative research. The results of this research show that linguistic deviations found in Shakespeare's works are stylistically varied, and may be misconstrued by foreign readers. This kind of deviation, in turn, may give rise to misinterpretation and misunderstanding for foreign English readers.
\end{abstract}

Key words: linguistic deviation, stylistics, rhetoric, play, Shakespeare, licencia poetica

\section{Introduction}

There is no doubt that English is the most vital subject at schools and universities around the globe (Weda - Sakti, 2018: 718). For learners of foreign languages, especially English, an understanding of linguistic deviation is very important. However, linguistic deviation often disrupts the understanding of readers, especially foreign readers. Chaos may occur in syntactic aspects and in semantic aspects. The syntax is related to structure, both sentences, and phrases, whereas semantic is related to the field of meaning. Semantic fields are usually called notional categories considered with the complex of split-level means of their expression in a certain language; these categories interact each other because of the prevalence of their semantic functions (Ptashki, 2015).

Stylistics is the field of study or the study of the style of language used by someone or an author in expressing thoughts, ideas. In the style of language, language forestry is increasingly visible to influence readers. The power of language use can be found in rhetoric figures. This is one characteristic of the language used by Shakespeare in his works. Stylistics can also be defined as a means used by the author to achieve a goal, such as the beauty of sound because stylistics is a way to express the mind, soul, and personality of the author in his or her unique way. It is a linguistic part that focuses on variations in language use but does not exclusively give special attention to the use of complex languages in literary works. In stylistic, the division of

XLinguae, Volume 12 Issue 1, January 2019, ISSN 1337-8384, eISSN 2453-711X 
language style is broadly under the Scheme and Trope. The Syntax is related to Scheme while Trope is related to Semantics.

This research is an attempt to explain the symptoms of language use as found in some of Shakespeare's works. The results of this study are very useful for English readers and learners in understanding the rules of language applied in stylistics.

\subsection{Linguistic deviation and stylistics}

Linguistic Deviation (LD) is a term used by linguists to describe distortion in the use of language (at least at lexical and grammatical levels). Leech (1969: 42-52) claims that there are 9 kinds of deviation found in poetry (according to his study on various poems collected over a period of time). These are as follows: a) lexical deviation, b) semantic deviation, c) phonological deviation, d) morphological deviation, e) syntactic deviation, f) register use deviation, g) historical deviation, and h) graphological deviation. In literary study, the linguistic deviation is often to happen since the licencia poetica or poetical licence of the authors.

In fact, LD does not only occur in literary works of poetry but also in other literary works, including dramas such as those written by Shakespeare. Over the centuries, readers can sense the various linguistic deviations in the works of Shakespeare.

Licencia poetica (LP) is a colloquial term in literary study, often also referred to more prosaically as poetical licence. LP occasionally refer to the rhetorical euphemism which is used for indicating linguistic distortion, the alternation of language construction or grammar, or recomposing the existing text made by the author in the name of art or beauty. There can be no doubt that, Shakespeare utilized LP for poetic effect in his plays. In the study of linguistics, the language used by authors which departs from general rules, both lexical and grammatical, is usually termed deviation. The term LD was first introduced by Leech when researching a number of poems in his studies. He later found numerous irregularities in the use of language from a linguistic perspective, a practice which he called 'linguistic deviation'.

The researcher claims that one interesting aspect of stylistics is the ability of the author to manipulate the language used for the sake of dramatic effect and rhetoric purposes, and that such manipulation can usually be referred to as LD. Furthermore, the researcher considers that Shakespeare was a playwright who could readily manipulate the language he used for personal identity and aesthetic purposes, as well as rhetoric effects. His rhetoric constructs used for aesthetic and dramatic effects are often evident in the form of forces and iconicity present in his works.

\subsection{Research questions}

Based on the topic of this research, the researcher formulated the following research questions: 1) What kind of Linguistic Deviation are present in Shakespeare's plays; 2) What form do the Rhetoric Figures of linguistic deviations in Shakespeare's plays take; and 3) How can knowledge and comprehension of these linguistic deviations and rhetoric figures assist English language learners to understand the works of Shakespeare.

The first question can be answered by exploring Shakespeare's plays through dialogues of character and soliloquy to find the linguistic deviations present. The second question can be achieved through a study of the stylistics of Shakespeare's language. The third question can be answered through a detailed descriptive explanation of the linguistic artifacts to assist readers (non-native speakers of English) to attain a better understanding of the linguistic deviations and stylistics used in Shakespeare's plays. 


\subsection{Objectives of the study}

The purpose of this study was formulated as follows: 1) to inventory a number of linguistic deviations contained in Shakespeare's works, 2) to find out the types of rhetorical style in Shakespeare's linguistic deviation, and 3) to determine to what the extent of respondents (non-native English) failed to understand the linguistic deviation in Shakespeare's works.

The first objective can be achieved by searching the texts of plays accurately. This also includes the kind of linguistic deviation reported by respondents. The second objective is to examine their scheme and trope and then to determine what type of rhetoric they belong to, and the third objective is to provide a questionnaire to respondents. The simple statistical method is used to find out in what cases for nonnative English failed to understand the linguistic deviation in Shakespeare's plays.

\section{Material and methods}

\subsection{Material}

This study examines the linguistic aspects of Shakespeare's works using the perspective of stylistics study. Only 10 of the 38 Shakespeare works were used as data sources. These were: 1) Romeo and Juliet (RJ), 2) King Henry V (KH), 3) Antony and Cleopatra (AC), 4) King Lear (KL), 5) Hamlet (HM), 6) The Merchant of Venice (MV), 7) Julius Caesar (JC), 8) Troilus and Cressida (TC), 9) King Richard II (KR), and 10) Measure for Measure (MM).

Primary data sources (Shakespeare's works) are compiled in a collection entitled "The Complete Works of Shakespeare", published in 2008 by Gedded \& Grossel, David Dale House, New Lamark, Scotland. For referencing this research data, it is done by mentioning it in succession: drama titles in short, Act, Scene and pages. For example (AC / V.II.218-219), read Antony and Cleopatra, Act V, scene II, page 218-219.

\subsection{Procedure}

The data of this study are drawn from each Shakespearean work (in 10 selected works) through decontextualization, that is, separating the pieces of dialogue, sentences, or phrases that are known to have linguistic deviation elements. For the purposes of the research discussion, an example of the case "Shakespeare's words unfamiliar in today English" has been shown in the following Table 1. The next step is to present 13 data (sampling) from various works to be tested on respondents. Respondents are gathered in a classroom, given sufficient explanation, they are then presented with each data one by one through the projector show. The respondents are given the opportunity to appreciate each question. The time available for each number is five minutes. There are three choices; a) guess the meaning and context, b) strongly confusing, and c) no idea at all. 
what you think about the linguistic deviation

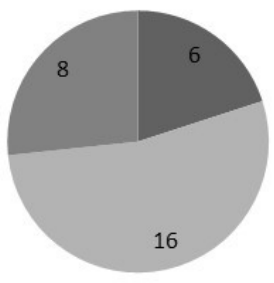

guess the meaning and contex

w strongly confusing

no idea at all

\section{Figure 1 Respondents' attitudes on the linguistic deviation}

\subsection{Respondents}

Respondents were 30 students of Literature of English Language Studies (ELS) Department of the Faculty of Cultural Sciences, Hasanuddin University Indonesia. The respondents are postgraduate students. They were instructed to answer multiple choice questions that have been prepared by the researcher. The option was set up 3 choices, namely a) agree, b) disagree, and c) neither agree nor disagree. The questionnaire was specifically designed to explore students' attitudes when facing linguistic deviation found in Shakespeare's literary works. For data retrieval, the respondents were instructed to answer the questionnaire in one spot place. They are like attending a diagnostic test. The instructions included the following:

1) Read the following instruction of question carefully. Tick your answer!

2) You do not need to write your name in the answer sheet

3) Answer (tick) one of the options: a) agree, b) disagree, and c) neither agree nor disagree. Remember! There is no any right or wrong answer for this assessment

4) Read the item as printed, no question about the item, the instruction is already clear.

The result of the assessment is presented in the following table.

Table 1. Respondents' assessment result

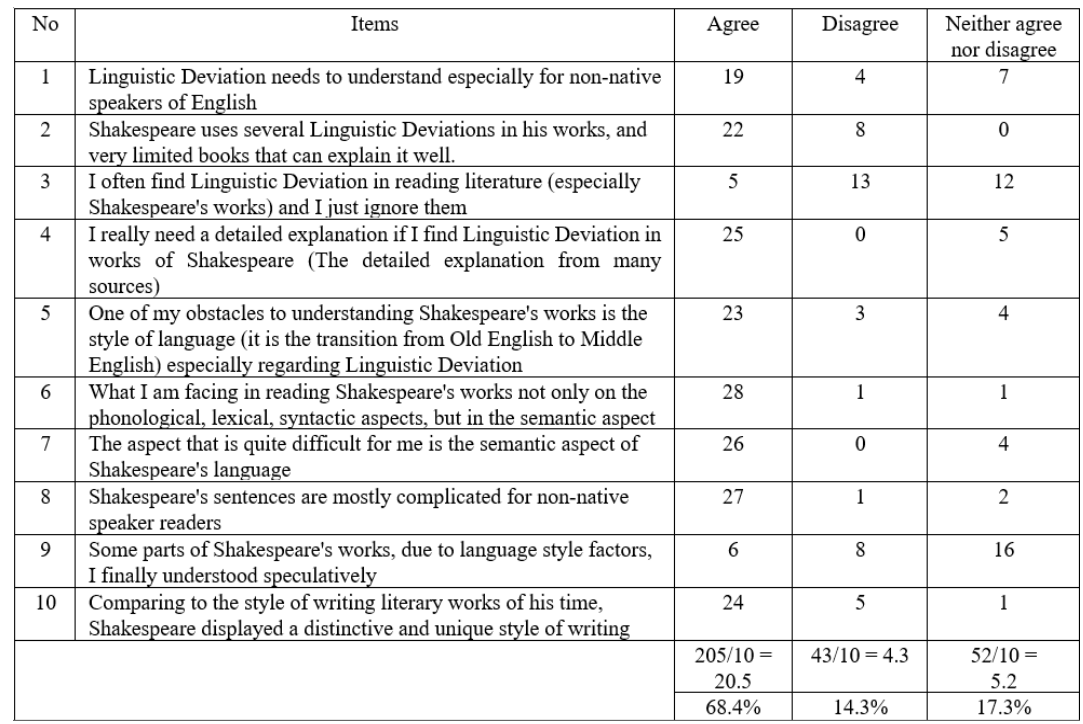


Based on Table 1 it can be seen that $68.4 \%$ said they agreed with the items asked in this assessment, this number dominated those who disagreed and who were neutral. This shows that LD can disturb the reader (especially a non-native speaker of English) when they are reading and the limit of their understanding of Shakespeare's works.

\subsection{Methodology}

This research aimed to identify the topic of Linguistic Deviation and Stylistics in Shakespeare's Plays. In order to achieve this goal, the following methodological steps and procedures were undertaken: 1) carefully examine the LD and the style used by Shakespeare in constructing his literary work through observation of data gathered from both primary and secondary data sources; 2) detect the existing LD's, based on the assumption that Shakespeare's LD was varied in style and rhetoric figures used; 3) decontextualize the utterances containing the LD; 4) describe the use of language with elements of LD; 5) categorization into rhetoric figures of style; and 6) outline a tentative conclusion.

The researcher made the assumption that, by adopting and adapting the general principles of corpus analysis (as shown the steps above), it would be possible to develop a bottom-up strategy, beginning by looking at the instances of language in order to arrive at generalizations about the significance of certain patterns, and then use a top-down approach for other points. By using this procedure, a theoretical construction could be developed.

The researcher considers that this new approach (perhaps more appropriately a new procedure) can bring to light new kinds of evidence. Thus, this study may help other researchers to validate and privilege certain interpretations, and perhaps even arrive at interpretations that have not been offered before.

\subsection{Data collection procedure}

The research data were sourced from several Shakespeare's works, as already mentioned above. Some of the procedures and methods of data collection are formulated as follows: 1) read the objects carefully as the primary data source, 2) identify the dialogues, who speaks to whom, and what the speaks intend to, 3) identify the part of the events, the relationship between speech events and characters action related to the topic, 4) list the conceptual points as preliminary LD, 5) list 'specific expression, keywords, symbol, name of places, proper name, and terms found in each works, 6) identify 'difficult words' (early modern English) that belong to the most applied in Shakespeare's plays, 7) build relationships between paradigmatic and syntagmatic of processed data, and 8) arranging the reference quotations in a row under the quotation; title (in abbreviation), act, scene, and lines.

Primary data is the data obtained from works intrinsically. In supporting the primary data, this study also made use of secondary data from the extrinsic element of the works. Thus, this study applies both literary study and the semantic one (languagebased analysis). The language-based analysis is introduced by Cummings and Simmons (1986:3). It may lead to reaching the objective of this study.

This study is a descriptive qualitative by using the structural and semantic approach of the works. The main data sources (primary data) of this study come from a number of Shakespeare's plays. Data collection techniques performed using analysis of documents (plays). The validity of data sources was done by using check and recheck method. This is also called "cross-examination". Data analysis using flow analysis consists of three components, namely data reduction, data presentation, and data verification as well as tentative conclusions.

\section{Shakespeare's language and plays}

\subsection{Shakespeare's language}

XLinguae, Volume 12 Issue 1, January 2019, ISSN 1337-8384, eISSN 2453-711X 
Most non-native of English speakers complain that Shakespeare's language is very hard to understand (Crystal, 1986:9). It is understandable that people may sometimes be a little overwhelmed when reading Shakespeare, since language is always evolving, and nowadays some of the words used in Shakespeare's plays can have a very different meaning from that which was current when the plays were created, while a number of words or grammatical constructions are no longer used in modern English. Some examples (Bloomfield, 1981:xiv) are as follows:

- "Thou" as "you." For example: "Thou art a villain."

- "Thee" as "you." For example: "When will I see thee next?"

- "Thy as "your." For example: "Thy name is more hateful than thy face."

- "Hath" as "has." For example: "He hath killed many a man." OR "He hath a horse"

In Shakespeare's plays, certain parts of speech are frequently switched and "normal" sentence order is frequently varied, often for the sake of rhyme or meter (which is related to rhythm). He often played with non-standard English; some common features include:

- Nouns or adjectives used as verbs

- Verbs and subjects which don't agree

- The use of implied words or omissions

- Word endings such as "-ly" applied inconsistently

- Some tricky sentence constructions.

For instance, consider the simple, normal sentence: "John caught the ball". Shakespeare might write this as "John the ball caught," or even "The ball John caught" (Shakespeare's Grammar).

In fact, the English language has already changed a great deal over the last few hundred years, and it is assuredly still changing. A list of some of the most common words used in Shakespeare's time and works which might not be familiar in English today, as they either have different meanings or have nearly been forgotten, are shown in Table 2. 
Table 2. Shakespeare's unfamiliar words in today's English

\begin{tabular}{|c|c|}
\hline Words & Expressions/Statements \\
\hline art-are, OR skill ..... & "Thou art dead; no phvsician's art can save you." \\
\hline hie-hurry ..... & "Hie thee hence, or lose your life!" \\
\hline ere -before ..... & "We must leave ere daybreak." \\
\hline fain -gladly ...... & $\begin{array}{l}\text { "I fain would bake Mr. Love cookies if I could get } \\
\text { an A." }\end{array}$ \\
\hline $\begin{array}{l}\text { anon -right now, right away, OR "I } \\
\text { come right away"..... }\end{array}$ & "Anon, good nurse! Speak!" \\
\hline $\begin{array}{l}\text { fie-an exclamation of dismay or } \\
\text { disgust ..... }\end{array}$ & $\begin{array}{l}\text { "You cheated? Fie upon it!" OR "Fie! Are you } \\
\text { mad?" }\end{array}$ \\
\hline hark-listen ..... & $\begin{array}{l}\text { "Hark to the owl," OR "Hark! The herald angels } \\
\text { sing!" }\end{array}$ \\
\hline doth or dost-does or do ..... & "Dost thou know the time?" \\
\hline hence-away ..... & $\begin{array}{c}\text { "Get thee hence, beggar!" OR "We must hence } \\
\text { before the army arrives." }\end{array}$ \\
\hline wherefore—why ..... & $\begin{array}{l}\text { "Wherefore dost thou leave?" OR "Romeo, } \\
\text { Romeo, wherefore art thou Romeo?" } \\
\text { [As in, "why can't you be someone } \\
\text { else, whom my family doesn't hate?"] }\end{array}$ \\
\hline hither-here ..... & Come hither, young lad." \\
\hline thither-there ..... & "Thither hath he ridden with the news." \\
\hline ho-hey (roughly equivalent). & "Lucius, ho!" [Brutus calling his servant] \\
\hline marry-indeed ..... & $\begin{array}{l}\text { "He says I should respond quickly; marry, I want } \\
\text { to." }\end{array}$ \\
\hline $\begin{array}{l}\text { pray/prithee — a polite way of asking } \\
\text { something ..... }\end{array}$ & "I prithee answer the question." \\
\hline saucy_cheeky; sassy ..... & "Hence, thou saucy boy!" \\
\hline hath—has ..... & $\begin{array}{l}\text { "He hath killed many a man." OR "He hath a } \\
\text { horse." }\end{array}$ \\
\hline $\begin{array}{l}\text { sirrah-a term of address used for } \\
\text { inferiors ..... }\end{array}$ & "Sirrah, bring the letter over here." \\
\hline whence_from where ..... & $\begin{array}{l}\text { "Whence came that news?" OR "Return to whence } \\
\text { you came." }\end{array}$ \\
\hline mark-pay attention to ..... & "Mark my words." \\
\hline
\end{tabular}

\subsection{Shakespeare and his works}

William Shakespeare is a well-known author in the world. He and his plays have the reputation of being among the greatest of authors and works in the English language and in Western literature. Traditionally, his 38 plays are divided into three genres. They are tragedy, history and comedy. In fact, they have been translated into every major language in the world, in addition to being continually performed all over the world.

Many of Shakespeare's plays originally appeared in a printing quartos series, but half around of them until 1623 were still remained unpublished, when the

XLinguae, Volume 12 Issue 1, January 2019, ISSN 1337-8384, eISSN 2453-711X 
posthumous First Folio was published. Based on the traditional divisions of the plays, they were categorized into tragedies, comedies and histories following the categories used in what we called the First Folio. However, a number of modern critics have named them or some of them as "problem plays" which elude easy categorization, or perhaps purposely break generic conventions. What we called romance has been introduced for what scholars believe to be his later comedies. The categorization used in this research was based on the commonly accepted classification of Shakespeare's plays, as shown in Table 3.

Table 3. The categorical distribution of Shakespeare's plays

\begin{tabular}{|c|l|l|l|}
\hline No & Category & Number of Works & Remarks \\
\hline 1 & History & 16 & \\
\hline 2 & Comedy & 12 & \\
\hline 3 & Tragedy & 10 & \\
\hline \multicolumn{2}{|c|}{ Total } & 38 plays & \\
\hline
\end{tabular}

In this article, representative LD's used in Shakespeare's plays were gathered from 10 plays. These were: 1) Romeo and Juliet; 2) King Henry V; 3) Antony and Cleopatra; 4) King Lear; 5) Hamlet; 6) The Merchant of Venice; 7) Julius Caesar; 8) Troilus and Cressida; 9), King Richard II; and 10) Measure for Measure. The types of LD found and their sources are shown in Table 4.

Table 4. The main types and sources of LD found in 10 Shakespeare plays

\begin{tabular}{|c|c|c|c|}
\hline No & Title of the Play & Linguistic Deviation Types & Rhetoric Figures \\
\hline 1 & Romeo and Juliet & - Semantic & - Paronomasia \\
\hline 2 & King Henry V & - Semantic & - Hypallage \\
\hline 3 & Antony and Cleopatra & - Syntactic & - Hypallage \\
\hline 4 & King Lear & - Lexical & - Aphaearesis \\
\hline 5 & Hamlet & - Lexical & - Aphaearesis \\
\hline 6 & The Merchant of Venice & $\begin{array}{l}\text { - Lexical } \\
\text { - Lexical }\end{array}$ & $\begin{array}{l}\text { - Neologism } \\
\text { - Apocope }\end{array}$ \\
\hline 7 & Julius Caesar & $\begin{array}{l}\text { - Semantic } \\
\text { - Phonological }\end{array}$ & $\begin{array}{l}\text { - Paronomasia } \\
\text { - Paronomasia }\end{array}$ \\
\hline 8 & Troilus and Cressida & - Lexical & - Apocope \\
\hline 9 & King Richard II & $\begin{array}{l}\text { - Lexical } \\
\text { - Lexical }\end{array}$ & $\begin{array}{l}\text { - Neologism } \\
\text { - Polyptoton }\end{array}$ \\
\hline 10 & Measure for Measure & - Lexical & - Neologism \\
\hline
\end{tabular}

Table 3 above shows that the dominant type of LD was a lexical deviation, followed by semantic, phonological and syntactic deviations. The rhetoric figures were limited to apheresis, neologism, apocope, and polyptoton (lexical deviation), paronomasia and hypallage (semantic deviation), paronomasia (phonological deviation), and syntactic (syntactic deviation). Thus, it might seem that there was a relationship between the kind of LD and the rhetoric figures used. However, in fact, there is no definite relation between LD and rhetoric figure types. The same rhetoric figure (e.g. paronomasia) might be present with more than one linguistic deviation type.

\subsection{The rhetoric emotion in Shakespeare's plays}

Means of communication between the author and the reader (the so-called audience) include dialogue and soliloquy (Peng, 2008: 216). Through the dialogues 
and soliloquies, the author's message is transmitted to the reader or audience. This is the reason why dramas have sometimes come to be called dialogues, since their essential is usually contained in the dialogue. The power of the dialogue itself is rhetoric.

Rhetoric (Lyne, 2001:72) is the art of persuasive argument through writing or speech - the art of eloquence and charismatic language, while the rhetoric figure is a category of the figures of speech such as schemes and tropes. A trope is an artful deviation from principal or ordinary signification of a word, in other words, the trope can refer to the use of word, phrase or images where its meaning cannot be interpreted in normal way, while scheme is the deviation of words arrangement from the standard pattern to the artful words pattern (Verdonk, 1995:17).

Rhetoric based on Peirce's semiotic is being rediscovered, and this concept. Peirce's triadic theory and typology of the sign have been used as a model for interpreting the system of rhetorical figures; Pierce also developed a pragmatic theory of rhetoric (Noth, 1990:342).

Based on the conceptual framework outlined above, the author strongly believes that literary text is a good tool for tracing LDs used by authors in creating their works. Through the LD, the author often conveys an important implied message and meaning which the reader (audience) needs to interpret.

In communicating, understanding of LD is important to attain a more meaningful communication. In relation to rhetoric, this relates to the persuasiveness of the speaker to the listener (audience), author to readers, and performers to the audience, or the strength of the dialogue between the characters in the drama, and so forth.

The communication between author and reader/audience through the medium of the language used in dialogues (also via soliloquy) (Murphy, 2007:132). Misunderstanding and misinterpretation often occur due to the presence of various types of LD, especially for non-native speakers (foreign learners) of English (Figure 2).
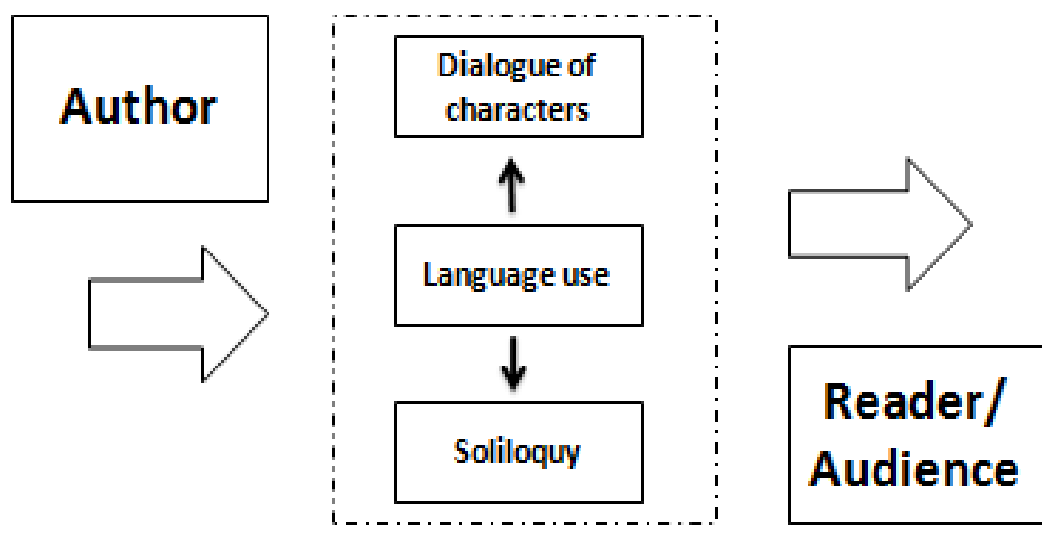

\section{Figure 2: Medium of communication between author and reader/audience (Murphy, 2007)}

With that point in mind, how does one make an argument persuasive enough to change the beliefs of another person? In classical Greek rhetoric, there are three basic approaches - three "rhetorical appeals"- one can use to make a convincing 
argument. They include these three items; a) logos (using logical arguments such as induction and deduction); b) pathos (creating an emotional reaction in the audience); and c) ethos (projecting a trustworthy, authoritative, or charismatic image)

In addition to balancing logic, emotion, and charisma, the rhetorician also has to adapt the argument, tone, and approach for the specific reader/audience. This reader/audience adaptation takes into account the assumptions of that reader/audience, and analyses the spoken and unspoken assumptions behind a specific line of argument.

\section{Linguistic deviation and the Significance of this study \\ 4.1 Linguistic deviations of Shakespeare}

In the present study, the researcher has found a number of LDs of hypallage, apheresis, apocope, enallage, and so on. For the sake of evidence, some examples are presented as follows:

\subsubsection{Deviation of syntax}

LD in syntax is also found somewhere in Shakespeare's plays. "John the ball caught" is a good example. Subject (S), Verb (V), Object (O) is the simplest pattern of sentences which mostly found in modern English. A subject (John), a verb (caught), and a noun (ball), when they are composed, will derive an understandable sentence, "John caught the ball." This case is exactly the same sentence in modern English as understood as in Shakespeare's era. However, Shakespeare often changes the pattern of these three basic components where he used a great deal of SOV inversions, which makes the sentence "John door kicked." This SOV pattern is commonly found in the German language where much English comes from its syntactical basis (Shakespeare's Grammar).

The use of such sentence patterns is considered by Shakespeare to be more practical where at that time the romance of Italian and French introduced rhythmic poetry. Since the introduction of this rhythmic poetic form there had been a shift in English poetry. Houston (qtd. Shakespeare's Grammar), "verbs in Old French and Italian make handy rhymes, and they make even better ones in English because many English verbs are monosyllabic". It is a natural development in the verse line or couplet comprising a subject near the beginning and a verb at the end.

It is certain that Shakespeare wrote his work in blank verse which mostly unrhymed "iambic pentameter" where at that time, Elizabethans allowed for a lot more leeway in word order. Shakespeare didn't only realize that, but he took as his advantage of it. In this case, Shakespeare was effectively putting the metrical stress wherever he wanted and thus English is very dependent on vocal inflection. In this case, English became very difficult to translate in suggesting emphasis and meaning. By using inversion order, Shakespeare could offset his literary shortcoming.

In another case, Shakespeare had also given many samples of word inversion on the sentence pattern used by using OSV (object, subject, and verb) which can be found such in the sentence "The ball John caught". It seems that Shakespeare employed this colloquially in many works as a transitory device to supply continuity especially in bridging two sentences. Besides that, Shakespeare also used the verb subject (VS) construction, "caught John" rather than "John caught", which seems like a stylistic choice.

Finally, according to Houston that, this happens might become the effort in making the language more memorable through the linguistic deviation of the spoken habits. It shows the essence of literature is to heighten the language even colloquial over that the prose, a heightening that produces an idealized, imaginative conception of the subject.

A good example of LD (syntactic) in the stylistic study is the basic set distinction within the grammar which distinguishes between different parts of speech. 
Consider now first that the following well-known lines from Shakespeare's Antony and Cleopatra (AC).Shakespeare writes;

1) “.... and I shall see some squeaking Cleopatra boy my greatness I the posture of a whoe"

(AC/V.II.218-219)

Now one of the basic set distinctions within the grammar which distinguishes between different parts of speech; and boy would, of course, be specific as a noun in the standard description of English. Here, however, it operates as a transitive verb. Shakespeare is consequently guilty of violating a grammatical rule [..]. In the case of the line from Shakespeare quoted above, the linguist can note that they constitute a deviant sentence and can specify where the deviance lies; the playwright has violated a 'category rule' by transferring the lexical item boy from the category of noun to the category of verb and more precisely to the sub-category of transitive verb (Widdowson, 1988).

\subsubsection{Hypallage}

Hypallage (combining two examples of hyperbaton or anastrophe) is characterized by the presence of the reversed elements are not grammatically or syntactically parallel. In this case, it is easier to give examples than to explain it. Look at the example, "The smell has brought the well-known breezes" when we would expect, in terms of proper cause-and-effect, to have "the breezes bring well-known smells." In King Henry V(KH), Shakespeare writes,

2) Our gayness and our gift are besmirched With rainy marching in the painful field"

(KH/IV.3.110)

When logically the reader would expect "with painful marching in the rainy field." Roethke playfully states, "Once upon a tree // I came across a time." In each example, not just one hyperbaton appears, but two when the two words switch places (inversion) with the two spots where we expect to find them. The result often seems to overlap with hysteron-proteron, in that case, it creates a catachresis.

Based on the illustration, it is found that the use of iconic force to make a convincing argument, respectively; a) logos (using logical arguments such as induction and deduction), b) pathos (creating an emotional reaction in the audience), and c) ethos (projecting a trustworthy, authoritative, or charismatic image).

\subsubsection{Aphaeresis}

Here, the researcher also proposes aphaeresis as one of LDs. Aphaeresis (also spelled apheresis; plural: aphaereses, adj. apheretic) is rhetorically deleting a syllable - unaccented or accented - from the beginning of a word to create a new term or phrasing. For instance, in King Lear (KL), we hear/read that,

3) "the king hath cause to plain"

Here, the word complain has lost its first syllable, com (com+plain). This kind of deviation also happens in Hamlet (HM), when Hamlet asks,

4) "'Who should 'scape whipping'

if every man were treated as he deserved.

$(\mathrm{HM} / \mathrm{II} / 2.534)$

XLinguae, Volume 12 Issue 1, January 2019, ISSN 1337-8384, eISSN 2453-711X 
For the case above, note that the $e$ - in escape has itself cleverly escaped from its position! It is an aphaeresis example of a rhetorical scheme or trope. It is clear this one contrasts with the more precise linguistic term aphesis. In the idea of aphesis, it linguistically operates the omission of an unaccented syllable from the front of a word. It strongly contrasts with the more general rhetorical term, aphaeresis.

\subsubsection{Apocope}

What to discuss then is apocope. In the case of apocope, it is to delete a syllable or letter from the end of a word. In The Merchant of Venice (MV), one character says,

5) "when I ope my lips let no dog bark,"

(MV/I.1.93-94)

Furthermore, the last syllable of open falls away into ope before the reader's eyes. This also happens in Troilus and Cressida (TC) (IV.5.148-150), Shakespeare proclaims,

6) "If I might in entreaties find success-

As seld I have the chance--I would desire

My famous cousin to our Grecian tents"

(TC/5.1.148-50)

Here, the word seldom becomes seld. This one belongs to apocope (the omission of a final part of a word). Based on the case, it is what the researcher needs to state clearly that apocope is an example of a rhetorical scheme. And it needs to note that some scholars modernize this word and refer to it as apocopation. It is really contrasted with syncope. Syncope is the omission of a medial part.In relation to the linguistic deviation, Shakespeare has placed many "guessing words" as a specific character of his works.

\subsubsection{Polyptoton}

Now we are on polyptoton rhetorical figure. As an instance of polyptoton consisting of two verb forms, a line from Richard II (KR/V.5. 49) can be quoted:

7) I wasted time,

and now doth time waste me'.

(KR/V.5. 49)

Here, the entire carrier of King Richard with its two faces -the period of incompetent rule and the period of his decline-finds a rhetorical equivalent in the grammatical change from the subject position ('I wasted') to the object position ('wastes me') and the change of the tense-form of the verb iconizes a change of fortune.

Furthermore, the misuse of grammar might be one interesting case in the discussion of LD. This method is very linguistics. It is about enallage. This term is derived from Greek, meaning an "interchange". Here Shakespeare is intentionally misusing grammar to characterize his character (speaker) or to create a memorable phrase (to his reader or audience). In daily life, the current deviations are also seen in advertisement language such as "We was robbed!", or "You pays your money, and you takes your chances."

\subsubsection{Neologism}

As has already been described earlier that Shakespeare lived during the early modern English. Consequently, in addition to the poetical license, or for an 
artistic reason, it is meant to upgrade the emotional effect and sense of beauty for the readers (audience). Shakespeare also used a lot of big words and are rarely found in the English language today, such as thy'ld, never found any more. In stylistics, the use of words such as so-called neologism.

Neologism is a made-up word that is not a part of normal everyday vocabulary. As a matter of fact, Shakespeare of Measure for Measure (MM) often invented new words for artistic reasons. For instance,

$$
\text { 8) 'I hold you as a thing ensky'd [enskied]." }
$$

In LD especially phonological deviation, this is called syncope, that is the omission of a medial part of a word. The word enskied implies that the girl should be placed in the heavens. Other Shakespearean examples include climature (a mix between climate and temperature) and abyssm (a blend between abyss and chasm), and compounded verbs like outface or un-king. Occasionally, the neologism is so useful, it becomes a part of common usage, such as the word new-fangled that Chaucer invented in the 1300s. The following quotations are examples from King Richard (KR) where LD has related to iconic forces:

9) Pardon me, if you please; if not, I pleas'd

Not to be pardon'd, am content withal

(KR/II.1.187-

10) A banish's traitor; all my treasury

Is yet but unfelt thanks, which more, enrich'd

(KR/II.1.187-189)

11) O villians, vipers, damn'd without!

Dogs, easily won to fawn on any man!

Snakes, in my heath-blood warm'd

that sting my heart

189)

(KR/II.1.187-

One of Shakespeare's contributions to the enrichment of the English vocabulary is by creating some neologisms. The interesting thing about those examples are that there is an iconic relationship of each, such as [pleas'd with 'pardon]', ['treasury and enrich'd] and [vipers and snakes].

A neologism may be considered either a rhetorical scheme or a rhetorical trope, depending upon whose scholarly definition the reader trusts for. Neologism is generally divided into five types namely compounding, infixation, epenthesis, proparalepsis, and prosthesis, eventhough some of them are not found in the gathered data.

\subsubsection{Paronomasia}

The point of paronomasia is that a mere accidental phonetic relationship assumes the appearance of a semantic relationship. It seems the words couple in paronomasia may have a different or contrasting or even contradictory meaning. Here is, first, an instance of an antithetical relation of the punning words from Shakespeare's Romeo and Juliet (RJ) as shown below: 
(RJ/III.4.8)

The iconic impact of this pun lies in the fact that words of similar sound, but sharply contrasted meaning (woe-woo) are combined. The figure then reflects the contrarieties and antagonisms which dominate the whole action of the play. Furthermore, the fundamental problem of the play is iconized in miniature by such an antithetical combination of similar-sounding words, an effect which is also produced by the rhetorical figure of oxymoron which pervades the whole play. This case is commonly found in Shakespeare's plays.

The example above must be classified as an instance of endophoric iconicity (Moyle, 2001) since it has a clearly identifiable function in that an individual linguistic element is here an analog to the larger structure of the whole text.

A different case is to be found in the following instance of paronomasia, the pun contained in the climactic lines of Cassius' attempt to persuade Brutus to join the conspiracy against the eagerly/would be king Julius Caesar (JC) in Shakespeare's play,

13) Now is it Rome indeed, and room enough,

When there is in it but one only man.

(JC/I.2.155-156)

This pun, which relates the words "Rome" and "room", is iconic in that the phonetic similarity between the two words-according to Elizabethan pronunciation the pun might be conceived as a homonymic pun - coincides with a semantic correspondence. What Cassius protests against is that Rome is under the given circumstances in danger of losing its political identity, its status of being room for many people and not for one man, i.e. an autocratic ruler. The pun with its combination of different words of similar sound has a profound semiotic function. It is used to express the political ideal of Rome as a stronghold of republicanism. To make it unmistakably clear, the pun's iconicity is exophoric, because Cassius argues that "room" and "Rome" should be 'one and the same' reality.

\subsection{The significance of this study}

This study was designed with two objectives; theoretically and pragmatically. Theoretically, it is to examine that licentia poetica makes exceptions and authority to the author to treat language as reasons effect of meaning without considering the limitations of the reader's understanding. However, it is important to note that misinterpretation and misunderstanding can reduce the appreciation of literature for readers (Rees, 1973).

Pragmatically, this study will be useful, among others, the first to help the reader of Shakespeare's plays (especially for non-native speakers of English) to understand the style of the author though by way of LD. This kind of research will hopefully solve the problem of teaching English as a foreign language especially in reading Shakespeare's plays.

Things become obstacles for foreign speakers, in fact Elizabethan dialect is strongly different from Modern English as today, but it becomes obstacles even if they basically are mostly the same. In the present day, there are actually some anomalies that the prepositional usage, for instance, verb agreement and number of Shakespeare's words have shifted the meaning from the present vocabulary. What was then happened, the improvement of the language in the case with the word order from Middle to Early Modern English was slightly more flexible, although 
Shakespeare's prose, came as like the nonstandard prose that could give greater licenses in expression. As a result, the Elizabethan English period remains a sibship of the tongue, and eventually, accessible.

As for the significance of this research is expected to provide two keys of benefits, increase appreciation of literary works of Shakespeare and to enhance the knowledge of English especially for readers of non-native speakers of English. This research is designed to help the non-native of English, but not to give all the answer. It is simply to show a case that they can help for themselves.

\section{Conclusion}

As mentioned previously, LD can disturb the reader (especially a non-native speaker of English) and limit their understanding of Shakespeare's works. This research revealed a number of LDs, including a) Deviation of Syntax, b) Hypallage, c) Aphaearesis, d) Apocope, e) Polyptoton, f) Neologism, and g) Paronomasia. Shakespeare's linguistic deviation needs to be understood in modern English as it was Shakespeare's time.

The LD can be parsed from the stylistic elements, since in reality, the same LD may have different stylistic categories. That case was found in this research and is part of what makes this study of interest.

As this research shows that the linguistic deviation found in Shakespeare's works is stylistically varied, there is a high likelihood that specific instances will be misinterpreted especially by the foreign readers, and is likely to cause misinterpreted and lead to misunderstanding. However, the results of this study can help the reader to overcome this challenge through a better understanding of the linguistic deviations present in Shakespeare's works.

Finally, this study proves that the same LD may have different rhetoric figures, and vice versa, both in the same and or different works. The significance of this information can be applied to assist learners of English as a foreign language, through enhancing their familiarity with language stylistics, and the art with which Shakespeare employed various usages of the English language. It is often argued that Shakespeare is as relevant today as he was in his own time; through a deeper understanding of LD, non-native speakers of English may understand Shakespeare's true meaning with greater ease and proficiency, and thus come to truly appreciate his great literary works.

\section{Bibliographic references}

BLOOMFIELD, N. W. 1981. A Brief History of the English Language. In The American Heritage Dictionary of the English Language. Ed. William Morris. Boston: Houghton Mifflin Company. ISBN 0080286674

CRYSTAL, D. - DEREK, D. 1969. Investigating English Style. London: Longman. ISBN 978-0582550117

CUMMINGS, M. - ROBERT, S. 1986. The Language of Literature - A Stylistic Introduction to the Study of Literature. Frankfurt: Pergamon Press. ISBN: 0395874637

GEDDED - GOSSEL. 2008. The Complete Works of Shakespeare, David Dale House. Scotland: New Lamark. ISBN 1855349973

LEECH, G. N. 1969. A Linguistic Guide to English Poetry. London: Longman. ISBN 0582550130

LYNE, R 2011. Shakespeare, Rhetoric and Recognition. Mexico City: Cambridge University Press. ISBN 9781107007475

MOYLE, J. 2001. Where reading peters out Iconic images in the entropic text. From sign to signing: iconicity in language and literature 3. Eds. Wolfgang G. Müller and

XLinguae, Volume 12 Issue 1, January 2019, ISSN 1337-8384, eISSN 2453-711X 
Olga Fischer. Philadelphia: John Benjamins Publishing Company. ISBN 9781588112880

MURPHY, S. 2007. A Corpus Stylistic Approach to Shakespearean Soliloquies. Lancaster: Lancaster University Postgraduate Conference.

NOTH, W. 1990.Handbook of Semiotics. Bloomingtom and Indianapolis: Indiana University Press. ISBN 9780253209597

PENG, C. H. 2008. Who's the Addressee? Four Types of Shakespearean Soliloquy. Chang Gung Journal of Humanities and Social Sciences, pp. 203-222.

PTASKHIN, A. 2015. Semantic Field of biological constituent of deviation in English. XV International Conference "Linguistic and Cultural Studies: Traditions and Innovations", LKTI 2015, 9-11 November 2015, Tomsk, Russia. Procedia Social and Behavioral Sciences, Volume 206, pp. 51 - 55. ISSN 18770428.

REES, R.J. 1973. English Literature - An Introduction for Foreign Readers. Hongkong: Peninsula Press Ltd. ISBN 0333142810

SHAKESPEARE'S GRAMMAR. Shakespeare Resource Center. 2018. Available online: http://www.bardweb.net/content/grammar/01 syntax.html

VERDONK, P. 1995. Words, words, words. A Pragmatic and Socio-cognitive View of Lexical Repetition. Twentieth-Century Fiction from Text to Context. Eds. Peter Verdonk and Jean Jacques Weber. London: Routledge. ISBN 9780415105903

WEDA, SUKARDI - SAKTI, ANDI ELSA FADHILAH. 2018. The Relationship between Study Anxiety and Academic Performance among English Students. XLinguae, Volume 11, Issue 2, April 2018, pp. 718 - 727. ISSN 1337-8384, eISSN 2453-711X.

WIDDOWSON, H. G. 1988. Stylistics and the Teaching of Literature. London: Longman. ISBN 0582550769.

Words: 7688

Characters: 42708 (23,73 standard pages)

assoc. prof. Dr. Fathu Rahman, M.Hum.

Deputy Dean of Cultural Sciences Universitas Hasanuddin,

Jl. Perintis Kemerdekaan Km. 10 Makassar

Indonesia,

fathu.rahman@unhas.aci.d

assoc. prof. Dr. Sukardi Weda, S.S., M.Hum., M.Pd., M.Si., M.M., M.Sos.I., M.A.P. Head of English Literature Study Program Faculty of Languages and Literature Universitas Negeri Makassar Jl. Dg. Tata, Kampus UNM Parangtambung Makassar Indonesia sukardi.weda@unm.ac.id 